\title{
ASPEK MIKROBIOLOGI PADA PENYAKIT TROPIS YANG TERABAIKAN (MICROBIOLOGY ASPECT OF NEGLECTED TROPICAL DISEASES)
}

\author{
Oei Stefani Yuanita Widodo
}

\author{
Fakultas Kedokteran, Universitas Muhammadiyah Malang, J1. Bendungan Sutami No.188A, Kota Malang, \\ 65145, Indonesia 0341-551149
}

\begin{abstract}
Abstrak
Dalam beberapa dekade terahir, penyakit tropis yang terabaikan mulai mendapat sorotan dari berbagai negara dikarenakan meskipun angka kematiannya rendah tetapi angka kesakitan sangat tinggi. Dampak penyakit yang ditimbulkan tidak hanya secara langsung baik pada individu dan komunitas, tetapi juga tidak langsung terhadap skala perekonomian negara yang sangat merugikan. Pendekatan Mikrobiologis sangat diperlukan untuk menunjang diagnosis dan ketepatan pengobatan demi meminimalisir dampak dari penyakit tersebut.
\end{abstract}

\begin{abstract}
In last decades, neglected tropical diseases was gaining more and more attention from many nations due to its effect that was not only to personal (bigh morbidity) but also community even in county scale in term economic. Microbiology approach is one of major supporting point to accelerate both diagnose and management process in order to minimise the complication.
\end{abstract}

\section{Pendahuluan}

Penyakit tropis yang terabaikan (NTDs) mewakili sekelompok penyakit menular kronis yang menyerang terutama pada area sub-Sahara, Afrika, Asia dan Amerika Latin serta Karibia. WHO menyebutkan dalam laporan global mengenai penyakit tropis ini terdapat 17 penyakit tropis terabaikan (Neglected Tropical Disease) yang membutuhkan perhatian dunia. Disebut terabaikan karena seringkali diderita oleh masyarakat ekonomi lemah khususnya didaerah pedesaan yang miskin (Liese, 2010). P e n y a k it tersebut dianggap sebagai penyakit terabaikan karena mempunyai bebarapa karakter yaitu kurangnya perhatian dari pembuat kebijakan, kurang mendapat prioritas dalam strategi kesehatan, kurangnya penelitian terkait penyakit ini yang belum mencukupi alokasi dengan sumber yang terbatas serta sedikitnya intervensi yang diberikan (WHO, 2010)

Kelompok infeksi NTDs ini menimbulkan cacat kronis yang mengakibatkan gangguan pertumbuhan dan perkembangan anak didik intelektual dan kognitif, gangguan kehamilan, dan penurunan produktivitas pekerja dan akhirnya secara tidak langsung produktivitas ekonomi menurun. Banyak NTDs juga menyebabkan cacat, kebutaan dan gangguan yang secara psikologis mengakibatkan stigma sosial, serta secara keseluruhan NTDs menyebabkan kondisi morbiditas tinggi meski mortalitisnya rendah. Penyakit tersebut yang disebabkan oleh bakteri adalah treponematosis, leptospirosis dan kusta yang sangat endemis pada negara-negara berkembang di Afrika, Asia dan Amerika.

Untuk memerangi penyakit NDT ini perlu ditingkatkan kesadaran masyarakat atas dampak penyakit tersebut dan mempersiapkan pebentukan Dana Global untuk memerangi NDT. Namun tidak kalah penting usaha diagnosis dengan alat penunjang secara akurat agar mendapat pengobatan secara cepat, tepat dan mengurangi resiko komplikasi/ cacat dimasa depan. Pada makalah ini akan diterangkan secara singkat peran laboraturium dan aspek mikrobiologi untuk membantu diagnosis penyakit infeksi kelompok NDT.

\section{Morbus Hansen}

Morbus Hansen atau Kusta adalah penyakit infeksi kronik yang sudah dikenal sejak 1400 tahun sebelum masehi. Penyakit ini diidentifikasi oleh G.A. Hansen pada 1874 di Norwegia berbentuk batang lurus atau melengkung dengan panjang 1-8 $\mathrm{nm}$ dan diameter $0,3 \mathrm{~nm}$, tahan asam dan alkohol, dan hanya bisa dibiakkan pada jaringan tubuh hewan armodillo dan kera mangabey (Jewetz, 2007). Cara penularannya dapat melalui kontak lama atau inhalasi dengan kemampuan masa tunas sampai 40 tahun. Saraf perifer adalah afinitas pertama, lalu kulit dan mukosa traktus respiratori bagian atas kemudian meyebar organ lain kecuali susunan syaraf pusat. Kusta merupakan penyakit yang menyeramkan dan ditakuti oleh karena adanya mutilasi, ulserasi, dan deformitas yang menimbulkan masalah sosial, psikologis dan ekonomis.

Pemeriksaan mikroskopis untuk menunjang diagnosis kusta dibuat dari kerokan kulit atau ditempat lesi, mukosa hidung yang kemudian diwarnai dengan pewarna terhadap basil tahan asam, antara lain ZIEHL NEELSEN. Hasil bakterioskopik negatif pada seorang penderita, bukan berarti orang tersebut tidak mengandung M.leprae. Untuk konfirmasi diperiksa 10 tempat dan untuk rutin minimal 46 tempat, yaitu kedua cuping telinga bagian bawah tanpa melihat ada tidaknya lesi ditempat tersebut, dan 2-4 tempat lain yang paling aktif, yang paling eritematous dan paling infiltratif.

M. leprae tergolong basil tahan asam (BTA), akan tampak merah pada sediaan. Dibedakan bentuk batang 
utuh (solid), batang terputus (fragmented), dan butiran (granular) (Jewetz, 2007). Bentuk solid adalah adalah basil hidup, sedang fragmented dan granular bentuk mati. Bentuk hidup lebih berbahaya karena dapat berkembang biak dan dapat menularkan ke orang lain.

Kepadatan BTA tanpa membedakan solid dan non solid pada sebuah sediaan dinyatakan dengan indeks bakteri (I.B) dengan nilai 0 sampai 6+ menurut Ridley. 0 bila tidak ada BTA dalam 100 lapangan pandang (LP).

\begin{tabular}{|l|c|c|}
\hline \multicolumn{1}{|c|}{ Jumlah } & Lapang pandang & Intepretasi \\
\hline $\mathbf{1}-\mathbf{1 0}$ & 100 & +1 \\
\hline $\mathbf{1}-\mathbf{1 0}$ & 10 & +2 \\
\hline $\mathbf{1}-\mathbf{1 0}$ & 1 & +3 \\
\hline $\mathbf{1 1}-\mathbf{1 0 0}$ & 1 & +4 \\
\hline $\mathbf{1 0 1}-\mathbf{1 0 0 0}$ & 1 & +5 \\
\hline$>\mathbf{1 0 0 0}$ & 1 & +6 \\
\hline
\end{tabular}

Indeks Morfologi (IM) adalah persentase bentuk solid dibandingkan dengan jumlah solid dan non solid.

Pemeriksaan serologik kusta didasarkan atas terbentuknya antibodi pada tubuh seseorang yang terinfeksi oleh M.leprae. Macam pemeriksaannya adalah: Uji MLPA (Mycobacterium Leprae Particle Aglutination). Uji ELISA (Enzyme Linked Immuno-Sorbent Assay) dan ML disptick (Colina G, 2002).

\section{Treponematosis}

Penyakit ini dibedakan menjadi penyakit sifilis (disebabkan Treponema pallidum), penyakit yaws (Treponema pertenue), pinta (Treponema carateum) dan Bejel (treponema endemicum). Semua spirochaeta secara morfologis dan immunologis identik dengan Treponema pallidum (Jewetz, 2007). Spesies ini dapat dibedakan satu sama lain oleh pola infeksi pada manusia, berdasarkan distribusi geografis dan oleh sekuensing asam nukleat.

Frambusia (Jaw atau Patek) merupakan penyakit infeksi kulit menular non seksual (Matthew L, 2008), tumbuh subur terutama diiklim tropis didukung dengan faktor higiene yang buruk dan kepadatan penduduk yang mempercepat transmisinya. Deteksi dini dan pengobatan minimal 6 bulan setelah terdiagnosis mampu mengurangi komplikasi kecacatan yang ditimbulkan. Diagnosis dapat ditegakkan dengan pemeriksaan mikroskopik lapangan gelap atau pemeriksaan langsung FA (Fluorosence Antibody) dari eksudat yang berasal dari lesi primer atau sekunder. Tes serologis non treponemal untuk sifilis misalnya VDRL (Veneral Disease Research Laboratory), RPR (Rapid Plasma Reagin) reaktif pada stadium awal penyakit menjadi non reaktif setelah beberapa tahun kemudian, walapun tanpa terapi yang spesifik, dalam beberapa kasus penyakit ini memberikan hasil yang terus reaktif pada titer rendah seumur hidup. Tes serologis trepanomal, misalnya FTA-ABS
(Fluoroscence Treponemal antibody-absorbed), MHA-TP (Microhaemag-glutination assay for antibody to Treponema Pallidum) biasanya tetap reaktif seumur hidup.

Pinta merupakan treponematosis tertua didunia (Matthew L, 2008). Setelah bakteri penetrasi kedalam lesi, mereka akan berkembang biak secara cepat namun tidak bersifat invasif. Kelainan yang disebabkan berupa hiperpigmtasi dan atau depigmentasi dan hiperkeratosis pada ras kulit gelap (Jewetz, 2007). Pinta meskipun tidak menggangu kesehatan umum namun adanya gangguan kosmetik seringkali membuat penderita menjadi terasing secara sosial. Diagnosis ditegakkan berdaarkan lokasi geografik, manifestasi klinik, demografis organisme dalam eksudat dengan pemeriksaan mikroskopik lapangan gelap, kecuali pada stadium lanjut yang akromik, Uji serologik (VDRL dan FTS-abs) baru menjadi positif setelah timbul lesi sekunder biasanya bertahan seumur hidup.

Bejel merupakan penyakit yang menyerupai sifilis, dapat ditularkan secara nonvenerik. Ditemukan di daerah gurun Timur Tengah serta Afrika yang beriklim panas gersang dan kering (Matthew L, 2008). Sebagian besar kasus Bejel terutama terjadi pada anak kurang dari 15 tahun. Sementara frambusia dan pinta terjadi terutama didaerah pedesaan dilingkungan panas dan lembab. Tes laboratorik diperlukan untuk mengkonfirmasi diagnosis dengan lapangan gelap dari lesi awal dan spesimen biopsi dengan noda perak. Tes serologik tidak dapat membedakan treponemal dan non-treponemal.

\section{REFERENSI}

Collina G, Atypicalcutaneus mycobacteriosis diagnosed by polymeras chain reaction. Br J Dermatol, 2002, $147,781-4$

Jewets M, Medical Microbiology, Lange International Edition 24th ed, McGrawn-Hill, 2007

Matthew L, Bejel, Yaws, and Pinta, Merck Manual Home Heal 